\title{
Adaptability to Settlement Pattern and Choice of Subsistence Activities: Emergence of Material Culture within the Saribas Malay in Betong, Sarawak
}

\author{
Faridah Sahari ${ }^{1 *}$, Anna Durin $^{1}$, Rahah Hasan ${ }^{1}$, Shahren Ahmad Zaidi Adruce ${ }^{2}$ and Shahri Abdul Rahman ${ }^{2}$ \\ ${ }^{1}$ Faculty of Applied and Creative Art, Universiti Malaysia Sarawak \\ ${ }^{2}$ Faculty of Cognitive Sciences \& Human Development, Universiti Malaysia Sarawak
}

\begin{abstract}
Despite many job opportunities in the market and the challenges they have to face, some minority of the Saribas Malay community in Betong, Sarawak is still maintaining traditional subsistence activities in food production based on the nipah tree (locally known as apong) such as gula apong, garam apong cuka apong, jarik mayang, air sadap and the sago tree (locally known as mulong) produce, lemantak. This research examines the choice of subsistence strategies and settlement pattern of the Malay community who inhabit the Saribas region. Through the in-depth interview and participant observation, the finding suggested that reliance on a river as the main highway to connect them to the other parts of Sarawak and river as a source of marine resources determine the choice of linear settlement pattern along the river. The results also suggest that river terrestrial resources; apong and mulong accessibility and abundance availability that influence the community in continuing the traditional subsistence activities (apong and mulong based food production) related to those flora source. As such, the assemblage of material culture that exist within the Saribas Malay community is the representation and manifestation of their choice of settlement pattern and subsistence activities.
\end{abstract}

\section{Introduction : The Saribas Malay community}

The Saribas state has long existed. According to Sanib (2012, 2013), the Saribas, was among the other four Lost Kingdoms toponyms; Sarawak, Samarahan, Kalaka and Melanau, that appeared in the Brunei Sultanate various manuscripts and in the Javanese chronicle ever since 1365. Due to restricted sources of the Saribas Malay available in the present, this paper is an early attempts to documenting the material culture of the people of once been the prominent state in the Sarawak history. Three aspects of Saribas Malay are discussed in this paper: settlement pattern, livelihood strategy and material culture that emerge from the sustenance activities of the community; which is based on the premise that these three aspects are interrelated and characterized by their environment.

Cultural diversity of a community is affected by various factors associated with the customs, traditions, ways and lifestyle of the community. The objects of the Sarawak Malay culture are closely related to socioeconomic activities, and each one has its function and role, and vary significantly with the Malay in Peninsular Malaysia (Awang Azman, 2014). In fact, the term (in Sarawak dialect) used for the cultural objects is also unique among the Malay community from different parts of Sarawak (Mary Fatimah and Salbia, 2014).

\footnotetext{
${ }^{*}$ Corresponding author: sfaridah@unimas.my
} 
The Malays constitute the majority of the people in Betong Division. According to data released in 2013 by the Sarawak Planning Unit (SPU), the two colonies in the division administration, Betong and Saratok cover an area of $4181 \mathrm{~km}$ square and $59,000(52 \%)$ of the total 114,000 population is Malay.

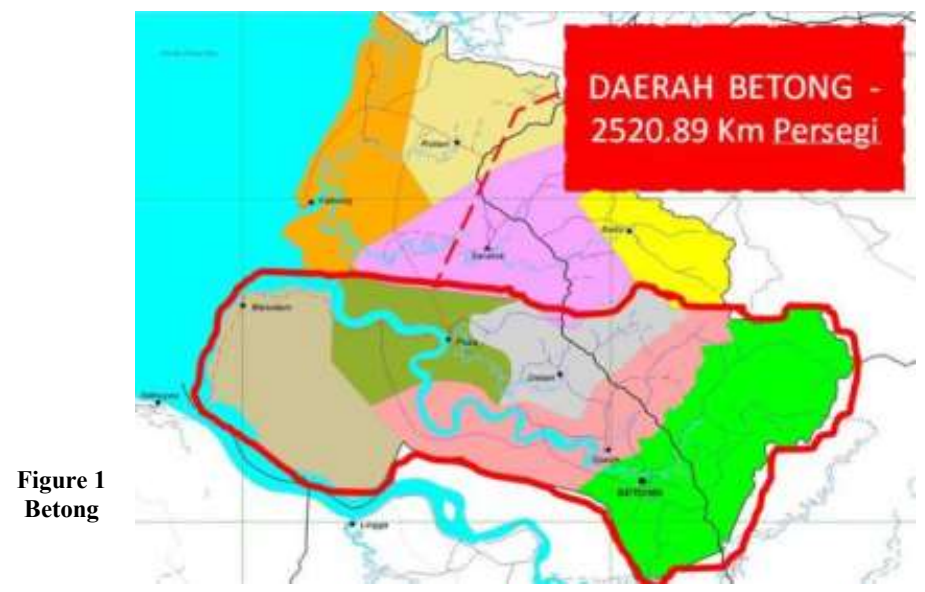

Betong District Map (Source: District Council, 2017)

Table 1 shows the population by ethnic group of five sub-districts of Betong, and Malay appeared to be the largest population in Pusa. This paper is about the Saribas Malay of Tambak, Pusa in Betong Divison Sarawak. The location is selected based on the active apong and mulong related activity in the area.

Table 1 Total Population by ethnic group, sub-district and state, Malaysia, 2010 (Source: Department of Statistics Malaysia)

\begin{tabular}{|c|c|c|c|c|c|c|c|c|c|c|c|c|}
\hline \multirow{3}{*}{ 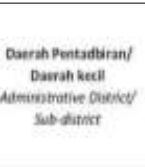 } & \multirow[t]{3}{*}{$\begin{array}{l}\text { fentah } \\
\text { fotal }\end{array}$} & \multicolumn{10}{|c|}{ 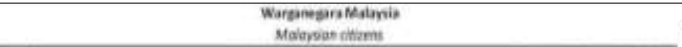 } & \multirow{3}{*}{ 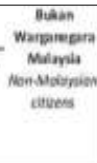 } \\
\hline & & \multirow{2}{*}{$\begin{array}{l}\text { Tumblis } \\
\text { fenif }\end{array}$} & \multicolumn{6}{|c|}{ Aumpouten } & \multirow{2}{*}{$\underset{\text { Cinese }}{\text { Cins }}$} & \multirow{2}{*}{$\begin{array}{l}\text { hodia } \\
\text { indiant }\end{array}$} & \multirow{2}{*}{$\begin{array}{l}\text { Lowtain } \\
\text { onen }\end{array}$} & \\
\hline & & & $\begin{array}{l}\text { Jumiah } \\
\text { Tata }\end{array}$ & $\begin{array}{l}\text { Melapu } \\
\text { Muliay }\end{array}$ & hat & Mitayuh & Meiata & 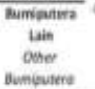 & & & & \\
\hline METONE & 6093 & is.ne & 57.70 & 3591 & $n, 2 n$ & 19s. & wat & $1 n$ & $2 m$ & u & n & su \\
\hline Antone & 17,014 & 15,555 & 15351 & 276 & $12 / m z$ & 116 & 60 & a & Lng & 20 & as & 9\% \\
\hline Qebak & 20276 & 10,206 & 2753 & 4,487 & $3 \times 2$ & 33 & 12 & 15 & $\$ 1$ & 5 & 14 & $N$ \\
\hline Mvidam & 5901 & $5,0 \times 5$ & sin? & 601 & $\mathrm{~kg}$ & $\mathrm{n}$ & 15. & a & 106 & 1 & 2 & $n$ \\
\hline nis & 1692 & 14,625 & 14,422 & एव:ग & aix & ut & 38 & 16 & 190 & 5 & $t$ & 293 \\
\hline bach: & 12,616 & 12,404 & $12 \times 1$ & 3509 & 2652 & 14 & is & u & 34) & 3 & 2 & $\mathbf{u}$ \\
\hline
\end{tabular}

\section{The relationship between settlement pattern, environment and subsistence activity \\ 2.1 Settlement pattern and environment}

The Saribas Malay was named after a name of a river, which is Batang (local term for river) Saribas. The Malay community was settled near the river bank and along the coastal line of Saribas River and since the mid of the $16^{\text {th }}$ century, they barter traded the salt and salted fish with the Dayak for rice and jungle produce (Sabihah, 1972). The barter trade materials (salt; presumably garam apong and salted fish) mentioned in Sabihah's article suggest that, ever since the $16^{\text {th }}$ century, the Saribas Malay have relied on the river and its terrestrial resources in their food production technology and subsistence activities.

Figure 2 shows the distribution of major forest types in Sarawak, indicates the intensified of peat swamp forest in the region of Betong district. The geomorphology of this type of forest is on low, swampy and muddy land near to brackish river water terrestrial. Here is where apong (nipah palm) and mulong (sago palm) grow, among other diverse typical swamp vegetation of river mangrove 
and peat swamp (Johnson, 1992; Tsuji K. et. al., 2011). That explains the abundance of these two plants, fringed along the riverside of the Saribas where the Malay village settlement area is situated.
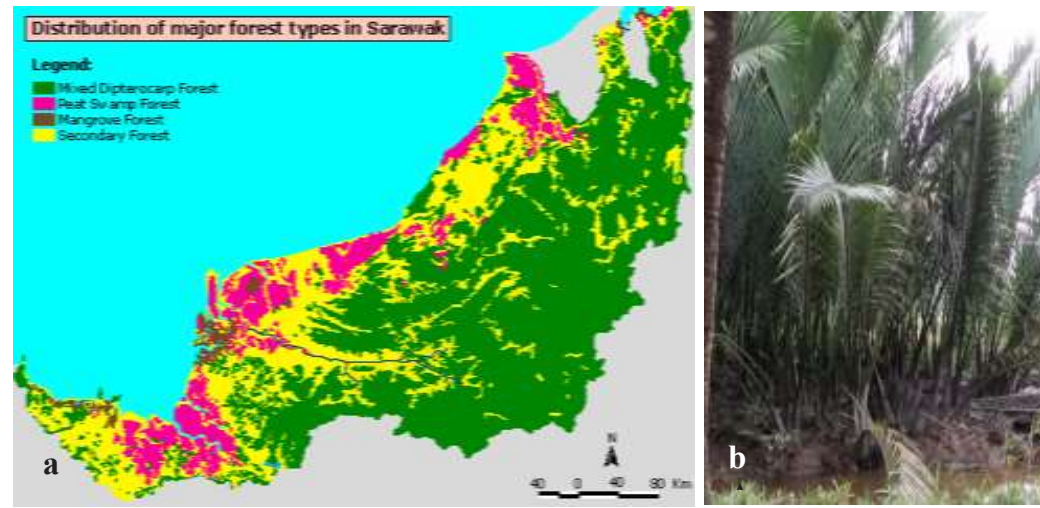

Figure 2 a) Forest Types in Sarawak (Source: Sarawak Forestry Corporation, 2017) and b) nipah palm tree

Despite wage labour employment and the scarcity of apong, economically, some minority of the Saribas Malay community in Kampung Tambak are still relying on that the palm tree as a main source of their subsistence activity; apong related food production. For the purpose of this study, the respondents are purposively selected based on two criteria: 1) their extended (15 to 20 years) of experience in gula apong production and 2) their families have been involved in in gula apong production for many generations. According to the respondents; Yahya, Rosman and Rosnah, their family had been relying on this activity a means of earning a living. Gula apong (palm sugar), garam apong (palm salt), cuka apong (palm vinegar) and lemantak (sago) are among the common foods related to apong and mulong produced by the community in Tambak, Pusa.

The researchers have been visiting the location of study for several times to interview the respective respondents and observe gula apong manufacturing process. Documentation is done through video recording and material culture inventory.

\subsection{Material objects emerged from gula apong production activity}

Next, the discussion will focus on the material culture that emerged from the gula apong production activity. The process begins with the preparation of the inflorescence stalk of nipah palm. The stalk can be chosen either from the young (mayang-flowering) or old (when the fruit is already beginning to form). But according to Yahya, the old inflorescence stalk is better since the sap can be harvested every day for three to four months. In the past, people shacked the stalk by hand and this process required tremendous effort and energy.
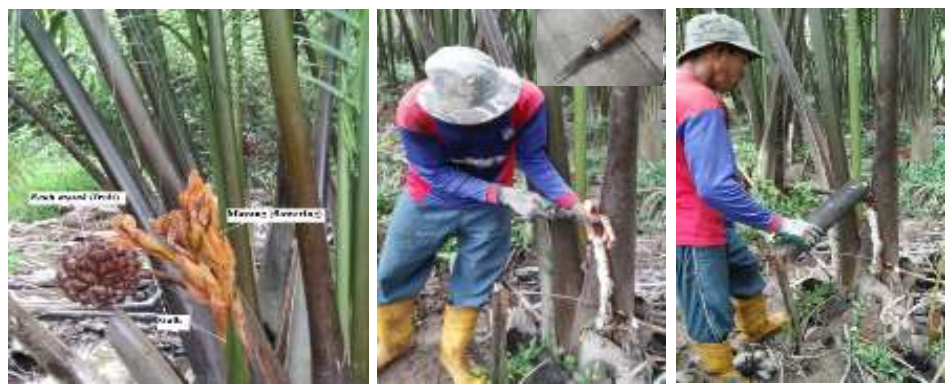

Figure 3 Nipah Palm Sap Tapping Process

Now, they beat the stalk using pemaluk matuk (a wooden beater) for the same purpose, to promote quicker and plenty of sap production. The process is repeated after three days for a month before the sap can be tapped and collected. The tapping process (menyabit) uses a specially made knife (pisok penyabit in Figure 3 inlet) to trim the stalk to remove surface crust and open the 
pores, and bamboo container (buluh tuak) is will then collect the sap. The tapping is done in the late afternoon and early in the next morning, the filled buluh tuak will be collected.

The local use buluh minyak or scientifically known as Bambusa vulgaris due to its properties, strong, light, straight stem, thinwalled and long clump interval. Air tuak spoils quickly (sour) due to the presence of water and impurities. Thus, the buluh tuak must always dry and clean. After use, the bamboo will be cleaned with ngujak (a brush made of nipah stalk) and dry and smoke on top of the hot clay stove.
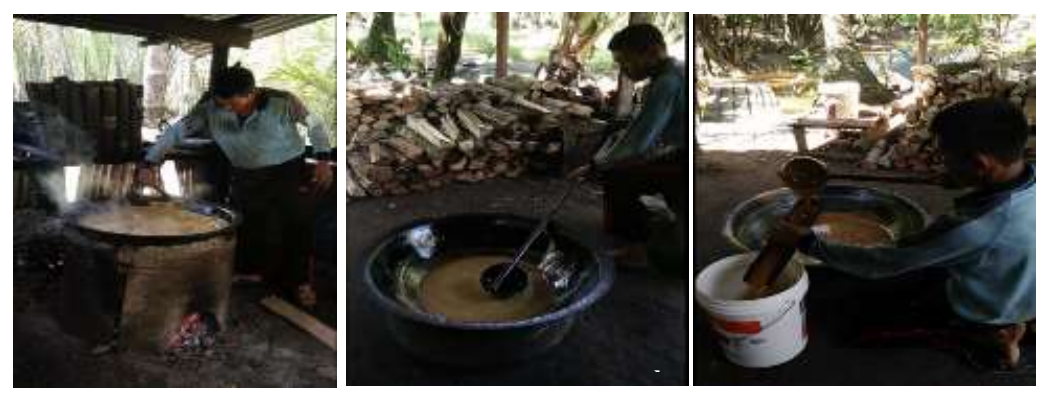

Figure 4 Material objects used in gula apong production a) buluh tuak, b) pemaluk, c) ngujak and d) ludan and solen
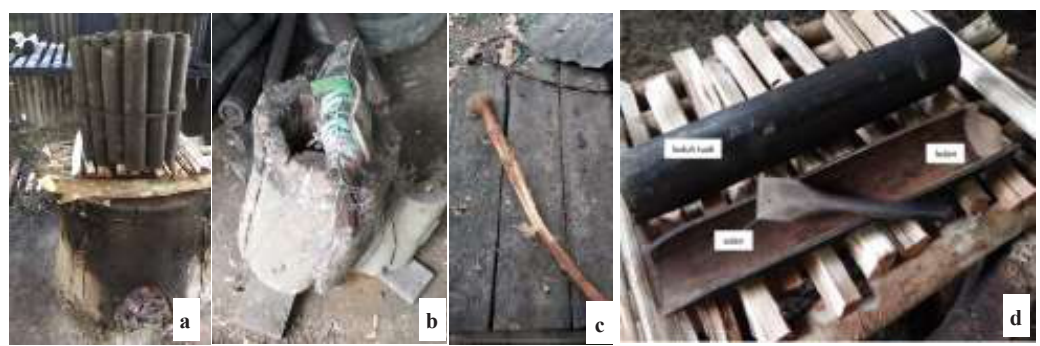

Figure 5 The use of (a) solen, (b) gayung and (c) ludan in gula apong production

The harvested air tuak is then brought to a dango (a processing plant) on the nipah palm site. The liquid pours into a big wok ( $k a h$ ) on top of a clay stove (kui) fire, using wood. A stirrer, made of coconut shell (gayung) to stir. Enggalang is used to avoid overflow of boiling syrup during the cooking process. In the past, enggalang was made of wood bark (preferably Meranti wood) which is now replaced by a custom made aluminium drum. Gula apong processing involves boiling the air tuak for several hours until the liquid is reduced by about $90 \%$ to a dark concentrated syrup that is sweet. The colour (yellowish, brown and dark brown) of the syrup is depending on the cooking time taken. The dark brown sugar taste bitter and inappropriate for cooking, but used to produce alcohol. When cooked, the gula apong is poured using ludan and solen (bamboo funnels and wooden spatula) into a container. 


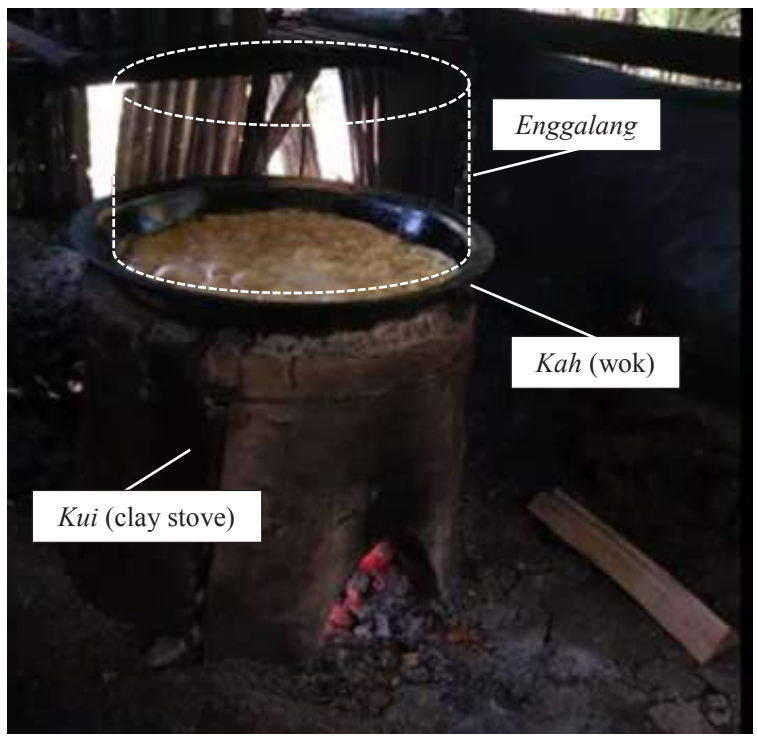

Figure 6 Cooking Materials

\subsection{Resources sustainability strategy}

As a gula apong producer, a person is commonly owned up to 500 nipah palm trees. To ensure the sustainability of resources, the nipah field is divided into blocks. Thus, the tapping process will cover one block at a time to provide sufficient time for the trees from the other blocks to recuperate before they can be tapped again. The dango is built near the nipah field and water source so the everyday routine of gula apong production is managed efficiently.
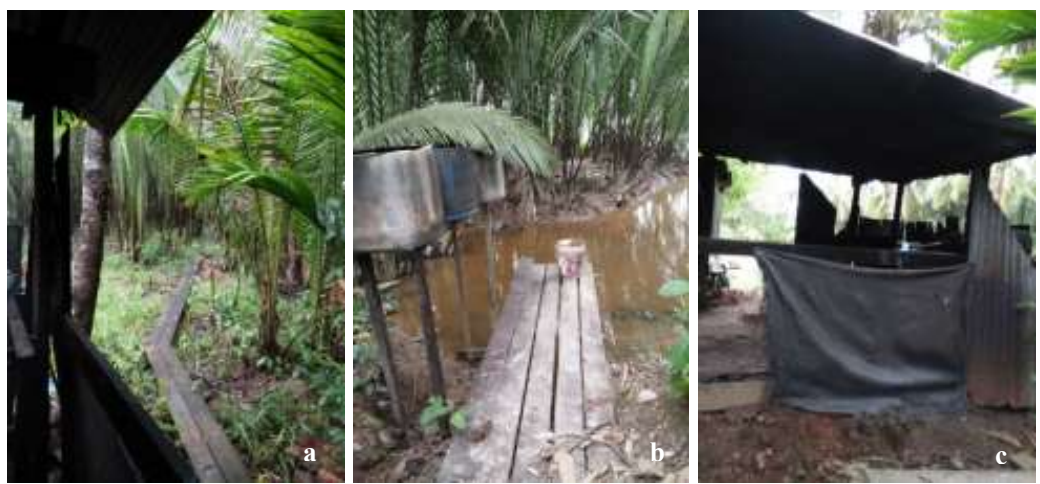

Figure 7 (a) Nipah field, (b) water source and (c) dango

\section{The continuity of traditional subsistence activity and settlement pattern}

The finding suggested that the Malay of Saribas is heavily reliant to a river (Batang Saribas) which becomes the major influence that determine their settlement pattern and subsistence activities which then shaped the material culture assemblage. The river continues to be the main highway to connect the community to the other parts of Sarawak and also as a source of marine resources determine the choice of linear settlement pattern along the river and fishing activities. The results also suggest that brackish water river terrestrial 
resources; apong and mulong accessibility and abundance availability that influence the community in continuing the traditional subsistence activities (apong and mulong based food production) related to those vegetation sources. Consequently, the assemblage of material culture that exist within the Saribas Malay community is the representation and manifestation of their choice of settlement pattern and subsistence activities.

\section{Conclusion}

The regional settlement pattern and environment of Saribas Malay in the context of Malay in Kg. Tambak, Pusa, Betong demonstrate the importance factor that reflects (1) choice of lifestyle and their subsistence activities as the community's strategy to adapt to settlement pattern and environment, (2) variants and designs of their material culture, use and choice of material and best practice in material culture production, and (3) natural resources sustainability strategy.

The abundance of nipah palm within their settlement and ecosystem play a significant role in the development of technology to effectively utilize the natural resources in food production technology; gula, garam, cuka and mayang, and it also directly influences the emerging of material culture related to that activity.

The authors wish to acknowledge the following entity and individuals that had been providing support for this study in various capacities.

1. UNIMAS Special Grant SSTG, Reference No. - F03/SpSTG/1571/2017- for providing financial and equipment support during the period of research.

2. Mr. Yahya Keram, Mr. Rosman Basuni and Ms. Rosnah Kadir for their assistance in the field.

\section{References}

1. Awang Azman Awang Pawi, Wajah Melayu Sarawak: Rampaian Ilmu Budaya (pp 187-210). Kota Samarahan: Universiti Malaysia Sarawak.

2. Johnson, D. V., World Wide Fund for Nature, \& International Union for Conservation of Nature and Natural Resources. (1991). Palms for human needs in Asia: Palm utilization and conservation in India, Indonesia, Malaysia and the Philippines. Rotterdam: Published for the World Wide Fund for Nature and for the World Conservation Union by A.A. Balkema.

3. Mary Fatima Subet dan Salbia Hassan (2014). Rahsia Kebahasaan Pantun Melayu Sarawak. In Awang Azman Awang Pawi, Wajah Melayu Sarawak: Rampaian ilmu budaya (pp 187-210). Kota Samarahan: Universiti Malaysia Sarawak.

4. Sabihah Osman, "Keadaan Masyarakat Bumiputera Sarawak pada Abad Kelapan Belas dan Awal Abad Kesembilan Belas: Satu Tinjauan Sejarah" dlm. Malaysia in History XV: 2, 1972.

5. Sanib Said, Penyelidikan Terkini di Malaysia, \& Institut Pengajian Asia Timur, Universiti Malaysia Sarawak. (2012). Sejarah Awal Kepulauan Melayu: Lima buah negeri warisan Sarawak yang hilang. Malaysia: The Ministry of Higher Education Malaysia.

6. Sanib Said, 2013. Melayu Sarawak: Sejarah yang Hilang. Kota Samarahan: Penerbit Universiti Malaysia Sarawak.

7. Tsuji K., Sebastian L.S., Ghazalli M.N.F., Ariffin Z., Nordin M.S., Khaidizar M.I., \& Dulloo M.E. (2011). Biological and ethnobotanical characteristics of Nipa Palm (Nypa fructicans wurmb.): A review. Sains Malaysiana, 40(12), 14071412 . 